African Crop Science Journal by African Crop Science Society is licensed under a Creative Commons Attribution 3.0 Uganda License. Based on a work at www.ajol.info/ and www.bioline.org.br/cs

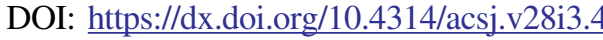

\title{
KARYOTYPE ANALYSIS OF TEN ACCESSIONS OF HAUSA POTATO IN NIGERIA
}

\author{
O.A.T. NAMO and C.I. EGBAJI
}

Cytogenetics and Plant Breeding Unit, Department of Plant Science and Biotechnology, University of Jos, P.M.B. 2084, Jos, Plateau State, Nigeria

Corresponding author: akunamo@yahoo.co.uk

(Received 27 January 2020; accepted 26 August 2020)

\begin{abstract}
Plant species may be classified according to their karyotype features. Variation in chromosome features is believed to have accompanied evolutionary divergence of many plant and animal species. The cytological characteristics of crop species vary with geographical location of plants. Knowledge of the karyotype relationships can be explored for effective genetic and breeding studies, especially in crops like the Hausa potato (Solenostemon rotundifolius) that have not received adequate research attention. This paper reports the results of the karyotype analysis of ten accessions of the Hausa potato cultivated in some parts of Nigeria. The accessions were raised in plastic bowls containing vermiculite soil, from which root-tips were harvested for slide preparation and karyotyping. The conventional squashing in aceto-orcein of root tissues after heating was used. The tissues were photographed under Nikon Universal Microscope, equipped with an MC 100 camera. The chromosomes were then measured under $\mathrm{x} 400$ magnification using a micrometer. Results showed that all the accessions were diploid with somatic chromosome number of $2 n=2 x=64$. The total length of longarms ranged from $108.80 \mu \mathrm{m}$ in accession Pankshin to $118.14 \mu \mathrm{m}$ in accession NRCRI (1). The total length of short arms ranged from $81.88 \mu \mathrm{m}-89.34 \mu \mathrm{m}$. The total length of long plus short arms ranged from $199.88 \mu \mathrm{m}-200.06 \mu \mathrm{m}$. The mitotic phases varied with accessions. Similarly, the arm ratio, $\mathrm{r}$-value, centromeric index, coefficient of variation, total form, intra-chromosomal index and inter-chromosomal index varied with the accessions. The accessions were grouped into four clusters: accessions Hong (1), Hong (2), Manchok and Gembu in cluster I; accessions Pankshin and Langtang in cluster II; accessions NRCRI (1) and NRCRI (2) in cluster III; accessions Bokkos (1) and Bokkos (2) in cluster IV. The principal component analysis showed that variation in the complement length and the centromeric position accounted for $99.997 \%$ of the total variation amongst the accessions. The study demonstrated that cytological differences exist in the Hausa potato. Some accessions showed close phylogenetic relationship, but others were distantly related. These differences could be explored for the improvement of the Hausa potato accessions cultivated in Nigeria.
\end{abstract}

Key Words: Centrometric index, Solenostemon rotundifolius (Poir) J.K. Morton 


\section{RÉSUMÉ}

Les espèces végétales peuvent être classées selon leurs caractéristiques de caryotype. On pense que la variation des caractéristiques chromosomiques a accompagné la divergence évolutive de nombreuses espèces végétales et animales. Les caractéristiques cytologiques des espèces cultivées varient selon la situation géographique des plantes. La connaissance des relations de caryotype peut être explorée pour des études génétiques et de sélection efficaces, en particulier dans des cultures comme la pomme de terre de Haoussa (Solenostemon rotundifolius) qui n'ont pas reçu une attention adéquate dans la recherche. Cet article présente les résultats de l'analyse du caryotype de dix accessions de la pomme de terre de Haoussa cultivée dans certaines régions du Nigéria. Les accessions ont été élevées dans des bols en plastique contenant de la terre de vermiculite, à partir desquels les extrémités des racines ont été récoltées pour la préparation des lames et le caryotypage. L'écrasement classique dans l'acétoorcéine des tissus racinaires après chauffage a été utilisé. Les tissus ont été photographiés au microscope universel Nikon, équipé d'une caméra MC 100. Les chromosomes ont ensuite été mesurés sous un grossissement $\mathrm{x} 400$ en utilisant un micromètre. Les résultats ont montré que toutes les accessions étaient diploïdes avec un nombre de chromosomes somatiques de $2 n=2 x=64$. La longueur totale des bras longs variait de 108,80 $\mu$ m dans l'accession Pankshin à 118,14 $\mu \mathrm{m}$ dans l'accession NRCRI (1). La longueur totale des bras courts variait de $81,88 \mu \mathrm{m}$ à $89,34 \mu \mathrm{m}$. La longueur totale des bras longs et courts variait de 199,88 $\mu \mathrm{m}$ à 200,06 $\mu \mathrm{m}$. Les phases mitotiques variaient avec les accessions. De même, le rapport de bras, la valeur $\mathrm{r}$, l'indice centromérique, le coefficient de variation, la forme totale, l'indice intra-chromosomique et l'indice inter-chromosomique variaient avec les accessions. Les accessions ont été regroupées en quatre groupes: les accessions Hong (1), Hong (2), Manchok et Gembu dans le groupe I; accessions Pankshin et Langtang dans le groupe II; accessions NRCRI (1) et NRCRI (2) dans le groupe III; accessions Bokkos (1) et Bokkos (2) dans le groupe IV. L'analyse en composantes principales a montré que la variation de la longueur du complément et de la position centromérique représentait $99,997 \%$ de la variation totale entre les accessions. L'étude a démontré qu'il existe des différences cytologiques chez la pomme de terre de Haoussa. Certaines accessions ont montré une relation phylogénétique étroite, mais d'autres étaient liées de loin. Ces différences pourraient être explorées pour l'amélioration des accessions de pommes de terre de Haoussa cultivées au Nigéria.

Mots Clés: Index centrométrique, Solenostemon rotundifolius (Poir) J.K. Morton

\section{INTRODUCTION}

Chromosome number is an important character used for evolutionary studies of plants, providing information about polyploidy and genome changes (Guerra, 2008; Louzada et al., 2010). Data generated from such studies are a useful tool for systematic comparisons of geographic and taxonomic groups of plants (Peruzzi et al., 2012). Karyotype analysis enhances understanding of phylogenetic relationships at different taxonomic levels.

In plant systematics, chromosome morphology and number are useful for the clarification of the origin and phylogenetic relationships of plants. Stebbins' classification has been used to assess the karyotype asymmetry and to establish karyotype relationship between different taxa (Stebbins, 1971; Cai et al., 2004; Pavlova and Tosheva, 2005; Eroglu et al., 2013; Ozcan et al., 2014). The centromere position and the relative chromosome length are the most important karyotypic features used to assess chromosomal affinities based on the concept of symmetry and asymmetry (Lavnia and Srivastava, 1992).

The Hausa potato [Solenostemon rotundifolius (Poir) J.K. Morton] is a tropical minor tuberous root crop $(2 n=2 x=64)$, with 
distinctive fragrance, medicinal, nutritional and economic values (Nanema et al., 2009). Species have been reported to have either metacentric or sub-metacentric chromosomes, which differ in length. Fujita (1970) reported variations in karyotype between and within plant species. Martin-Estra et al. (2011) reported the existence of intraspecific polyploidy within several species of the Lamiaceae family to which the Hausa potato belongs. The cytogenetic characteristics of crop species have been reported to vary with geographic location of the plants (Awe and Akpan, 2017). Most of the cultivated varieties of the Hausa potato in Nigeria are landraces held by smallholder farmers, which are yet to be scientifically characterised. These, like other plant species the world over, need to be continually documented and studied. There is the need for cytogenetic studies to establish the phylogenetic relationships of such species (Paknia and Karimzadeh, 2011; Onyutsetseg et al., 2013; Awe and Akpan, 2017). Data generated from such studies could be used to characterise and improve the crop species. This paper reports the results of the karyotype analysis of ten accessions of the Hausa potato cultivated in some parts of Nigeria.

\section{MATERIALS AND METHODS}

The seedlings were raised in the Biology Laboratory of the Department of Botany, Ahmadu Bello University, Zaria, Nigeria. The accessions used in this study were sourced from the germplasm collection of the National Root Crops Research Institute (NRCRI), Kuru and from some farmers in Manchok, Hong, Pankshin, Gembu, Langtang and Bokkos, spread across four states of Kaduna, Plateau, Adamawa and Taraba in Nigeria. These accessions include NRCRI (1), NRCRI (2), Manchok, Hong (1), Hong (2), Pankshin, Gembu, Langtang, Bokkos (1) and Bokkos (2). The agronomic characteristics of the accessions are shown in Table 1.

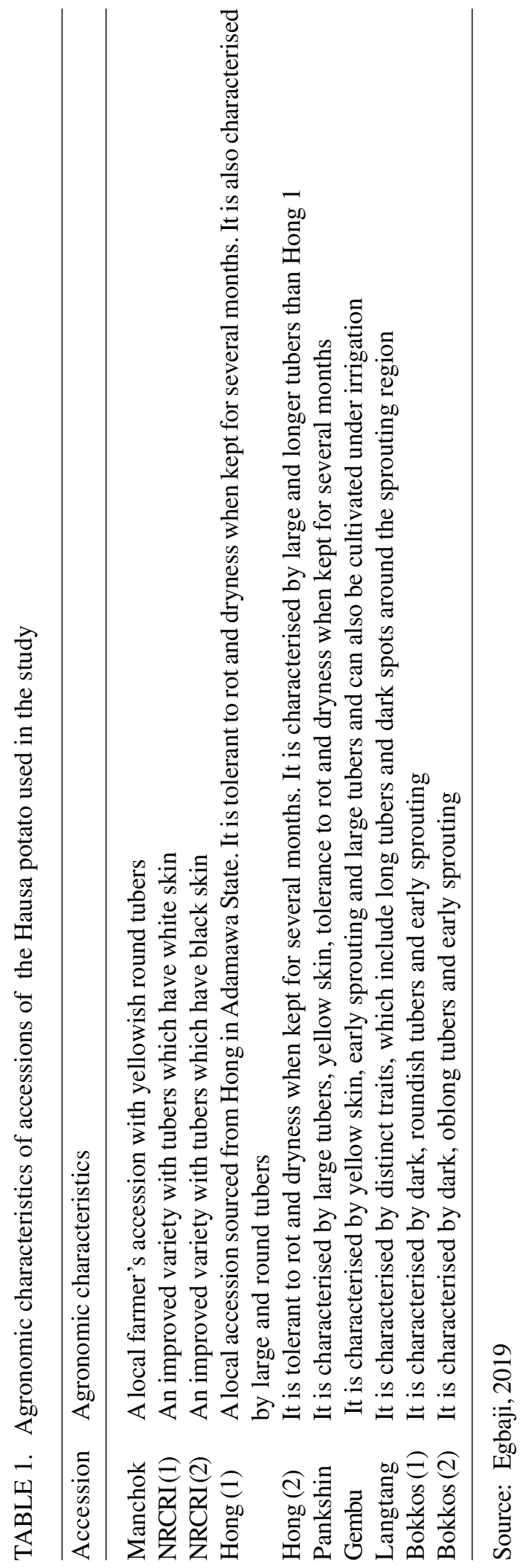


Karyotype study. Fresh root tips of 1-1.5 $\mathrm{cm}$ long were cut from rapidly growing seedlings (3-4 weeks after planting). The root tips were pre-treated with $0.5 \mathrm{~g}$ of Feulgen dissolved in $100 \mathrm{ml}$ of distilled water at room temperature for $3 \mathrm{hr}$. The roots were washed with distilled water for $5 \mathrm{~min}$ at room temperature; thereafter, they were fixed in Carnoy's fixative (glacial acetic acid: ethanol, $3: 1)$ overnight at room temperature $\left(25^{\circ} \mathrm{C}\right)$. After thorough washing with distilled water, $1 \mathrm{~N} \mathrm{HCl}$ was added using a dropper to hydrolyse the cells. The root tips were allowed to stand for 10 minutes to hydrolyse the cells. The $\mathrm{HCl}$ was removed from the Petri-dish using the dropper. The Petri-dish was then refilled with distilled water twice. A microscope slide was placed on a paper towel. Three drops of $2 \%$ aceto-orcein stain were placed in the centre of the slide. The root tip was transferred from the Petri-dish to the stain in the slide, using a pair of forceps, and was allowed to remain in the stain for 10-15 minutes to pick up the stain.

Triplicates of well-spread metaphase plates in terms of clarity and organisation, from different individuals, were processed and analysed for each accession. The best metaphase plates were photographed using an external camera (Celestron digital microscope imager 2.0) attached to the BX50 Olympus microscope, and scanned at 100-resolution. All measurements were recorded using the Software Image J (Abramoff et al., 2004). Chromosome morphology was described using nomenclatures proposed by Levan et al. (1964). Numerical characterisation was carried out on the following parameters:

The arm ratio (AR) was computed as the ratio of long arm length of a chromosome pair to the short arm length of the chromosome pair using the formula:

$$
\mathrm{AR}=\frac{L}{S}
$$
Equation 1

\section{Where:}

$\mathrm{L}=$ Long arm length of chromosome; and $\mathrm{S}=$ Short arm length of chromosome

The total chromosome length (TL) of each pair was calculated using the formula:

$\mathrm{TL}=\mathrm{L}+\mathrm{S}$ Equation 2

Where:

$\mathrm{L}=$ Long arm length; and $\mathrm{S}=$ Short arm length

The ratio of the shortest arm chromosome length to the longest arm chromosome length (r-value) was computed using the formula:

r-value $=\frac{S}{L}$ Equation 3

Where:

$\mathrm{S}=$ Short arm length of chromosome; and $\mathrm{L}=$ Long arm length of chromosome

The total form percentage ( $\% \mathrm{TF}$ ) was computed as the ratio of the summation of short arm length to the summation of long arm length and multiplied by one hundred (100) using the formula:

$\% \mathrm{TF}=\frac{\sum s}{\sum L} \times 100 \ldots \ldots \ldots \ldots \ldots \ldots \ldots \ldots . . .$. Equation 4

Where:

$\mathrm{L}=$ Long arm length of chromosomes; and $\mathrm{S}=$ Short arm length of chromosomes

The values of Dispersion Index (DI) of a given karyotype were estimated from the following equation:

$\mathrm{CG}=\frac{S X}{T L X} \times 100 \ldots \ldots \ldots \ldots \ldots \ldots \ldots \ldots . . . . .2$ Equation 5 
Where:

$\mathrm{CG}=$ Centromeric gradient; $\mathrm{Sx}=$ Length of median short arm; and $\mathrm{Lx}=$ Total length of median chromosome

$\mathrm{CV}=\frac{S D}{X} \times 100$ Equation 6

Where:

$\mathrm{SD}=$ Standard deviation, $\mathrm{X}=$ Mean chromosome length; and CV = Coefficient of variation for chromosome length; DI = Proportionate measure of $\mathrm{CG}$ with respect to CV.

Karyotype asymmetry was estimated using two numerical parameters according to the method of Romero-Zarco (1986) as follows:

$$
\begin{aligned}
& \sum_{1}^{n} \frac{S R}{L R} \\
& A_{1}=\underset{\mathrm{n}}{=\ldots \ldots}
\end{aligned}
$$

Where:

Sx $=$ Mean length of the short arm of each pair of homologues; and LX = Mean length of long arm of each chromosome

$\mathrm{n}=$ Number of homologues $(\mathrm{n}=32)$

$\mathrm{A}_{1}=$ Intrachromosomal index

$\mathrm{A}_{2}=\underline{\mathrm{S}}$

$\mathrm{X}$ Equation 8

Where:

$\mathrm{S}=$ Standard deviation,

$\mathrm{X}=$ Mean chromosome length; and

$=\mathrm{A}_{2=}$ Interchromosomal index

Statistical analysis. The data collected were subjected to the one-way analysis of variance (ANOVA) test, using the Statistical Analysis
System (SAS), version 9.2 software. Means were compared using the least significant difference (L.S.D) test at 5\% level of probability.

Cluster analysis was used to determine the relative closeness of one accession to the other so that all the accessions in the populations could be arranged in specific groups according to Peters and Martineli (1985). Cluster analysis was performed using the Cophenetic Coefficient (CP). Principal component analysis (PCA) was carried out to differentiate the studied populations based on the karyotype parameters. Dendrogram and principal component analysis (PCA) were analysed using the Unweighted Pair Group Method with Arithmetic Mean (UPGMA) software.

\section{RESULTS}

The short arm length varied from $1.285 \mu \mathrm{m}$ in accession NRCRI (1) to $1.431 \mu \mathrm{m}$ in the accession Pankshin (Table 2); but did not differ significantly among the ten accessions used in the study (Table 2). The total length was statistically similar in all the accessions of the Hausa potato studied (Table 2). The arm ratio varied from $1.189 \mu \mathrm{m}$ in the accession Pankshin to $1.438 \mu \mathrm{m}$ in the accession NRCRI (1) (Table 2).

The r-value varied from $0.695 \mu \mathrm{m}$ in accession NRCRI (1) to $1.844 \mu \mathrm{m}$ in accession Hong (1). The r-value did not also differ significantly $(\mathrm{P}>0.05)$ among the accessions of the Hausa potato studied (Table 2).

The coefficient of variation $(\mathrm{CV})$ varied from $14.00 \%$ in the accession NRCRI (1), to $32.50 \%$ in the accession Hong (2) (Table 3). The total form percentage of the Hausa potato accessions used in this study varied from $40.9 \%$ in the accession NRCRI (1) to $45.5 \%$ in the accession Pankshin (Table 3).

The highest disparity index of $50.8 \%$ was observed in accession Hong (2), followed by accessions Langtang (50.2\%), Hong (1) (49.8\%), Bokkos (2) (48.7\%), Manchok 
TABLE 2. Chromosomal characteristics of some Hausa potato accessions

\begin{tabular}{lllllll}
\hline Accession & $\begin{array}{l}\text { Short arm } \\
\text { length }(\mathrm{S}) \\
(\mu \mathrm{m})\end{array}$ & $\begin{array}{l}\text { Long arm } \\
\text { length }(\mathrm{L}) \\
(\mu \mathrm{m})\end{array}$ & $\begin{array}{l}\text { Total } \\
\text { length } \\
(\mathrm{L}+\mathrm{S}) \\
(\mu \mathrm{m})\end{array}$ & $\begin{array}{l}\text { Arm ratio } \\
(\mathrm{L} / \mathrm{S}) \\
(\mu \mathrm{m})\end{array}$ & $\begin{array}{l}\text { R-value } \\
(\mathrm{S} / \mathrm{L}) \\
(\mu \mathrm{m})\end{array}$ & $\begin{array}{l}\text { Centromeric } \\
\text { index } \\
(\mathrm{S} / \mathrm{L}+\mathrm{S}) \\
(\mu \mathrm{m})\end{array}$ \\
\hline Manchok & $1.362 \pm 0.122$ & $1.811 \pm 0.146$ & $3.173 \pm 1.589$ & $1.330 \pm 0.174$ & $0.752 \pm 0.094$ & $0.429 \pm 0.054$ \\
NRCRI(1) & $1.285 \pm 0.115$ & $1.848 \pm 0.189$ & $3.133 \pm 1.567$ & $1.438 \pm 0.180$ & $0.695 \pm 0.087$ & $0.410 \pm 0.051$ \\
NRCRI(2) & $1.359 \pm 0.178$ & $1.771 \pm 0.207$ & $3.130 \pm 1.565$ & $1.303 \pm 0.163$ & $0.767 \pm 0.096$ & $0.434 \pm 0.054$ \\
Hong (1) & $1.387 \pm 0.056$ & $1.728 \pm 0.118$ & $3.115 \pm 1.558$ & $1.250 \pm 0.156$ & $0.803 \pm 0.100$ & $0.445 \pm 0.056$ \\
Hong (2) & $1.398 \pm 0.071$ & $1.729 \pm 0.117$ & $3.127 \pm 1.564$ & $1.236 \pm 0.155$ & $0.809 \pm 0.101$ & $0.447 \pm 0.056$ \\
Pankshin & $1.431 \pm 0.134$ & $1.702 \pm 0.150$ & $3.133 \pm 1.567$ & $1.189 \pm 0.149$ & $0.841 \pm 0.105$ & $0.457 \pm 0.057$ \\
Gembu & $1.367 \pm 0.193$ & $1.733 \pm 0.022$ & $3.100 \pm 1.546$ & $1.270 \pm 0.158$ & $0.790 \pm 0.099$ & $0.441 \pm 0.055$ \\
Langtang & $1.373 \pm 0.101$ & $1.753 \pm 0.155$ & $3.126 \pm 1.563$ & $1.275 \pm 0.160$ & $0.783 \pm 0.098$ & $0.439 \pm 0.055$ \\
Bokkos (1) & $1.375 \pm 0.137$ & $1.754 \pm 0.151$ & $3.129 \pm 1.565$ & $1.276 \pm 0.159$ & $0.784 \pm 0.098$ & $0.439 \pm 0.055$ \\
Bokkos (2) & $1.366 \pm 0.381$ & $1.758 \pm 0.050$ & $3.124 \pm 0.562$ & $1.290 \pm 0.161$ & $0.777 \pm 0.098$ & $0.437 \pm 0.055$ \\
& & & & & & \\
LSD(0.05) & 0.361 & 0.462 & & & & \\
CV(\%) & 25.274 & 25.335 & & & & \\
\hline
\end{tabular}

TABLE 3. Haploid karyotype parameters measured in ten accessions of the Hausa potato cultivated in some parts of Nigeria

\begin{tabular}{lllllll}
\hline & CV & $\begin{array}{c}\text { TF } \\
(\%)\end{array}$ & $\begin{array}{c}\text { DI } \\
(\%)\end{array}$ & $\mathrm{A}_{1}$ & $\mathrm{~A}_{2}$ & $\mathrm{KF}$ \\
\hline Manchok & 14.5 & 42.1 & 47.8 & 0.022 & 0.039 & $28 \mathrm{M}+4 \mathrm{Sm}$ \\
NRCRI(1) & 14.5 & 40.9 & 39 & 0.021 & 0.046 & $25 \mathrm{M}+7 \mathrm{Sm}$ \\
NRCRI(2) & 14 & 43.5 & 42 & 0.024 & 0.06 & $29 \mathrm{M}+3 \mathrm{Sm}$ \\
Hong (1) & 30 & 44.7 & 49.8 & 0.025 & 0.029 & $32 \mathrm{M}$ \\
Hong (2) & 32.5 & 44.6 & 50.8 & 0.025 & 0.029 & $32 \mathrm{M}$ \\
Pankshin & 21.5 & 45.6 & 47.7 & 0.026 & 0.05 & $32 \mathrm{M}$ \\
Gembu & 21.8 & 43.5 & 45.7 & 0.024 & 0.065 & $30 \mathrm{M}+2 \mathrm{Sm}$ \\
Langtang & 25.59 & 43.9 & 50.2 & 0.025 & 0.039 & $30 \mathrm{M}+2 \mathrm{Sm}$ \\
Bokkos (1) & 26.59 & 43.9 & 45.6 & 0.025 & 0.023 & $26 \mathrm{M}+6 \mathrm{Sm}$ \\
Bokkos (2) & 28.9 & 43.9 & 48.7 & 0.024 & 0.047 & $30 \mathrm{M}+2 \mathrm{Sm}$ \\
\hline
\end{tabular}

$\mathrm{CV}=$ Coefficient of variations $; \mathrm{TF}=$ Total form; $\mathrm{DI}=$ Disparity index; $\mathrm{A}_{1}=$ Intrachromosomal index; $\mathrm{A}_{2}=$ Interchromosomal index; $\mathrm{KF}=$ Karyotype formula

(47.8\%), Pankshin (47.7\%), Gembu (45.7\%), Bokkos (1) (45.6\%) and NRCRI (2) (42.0\%). The lowest disparity index of $39.0 \%$ was observed in the accession NRCRI (1) (Table 3).

The intrachromosomal index ranged from 0.021 in accession NRCRI (1) to 0.026 in accession Pankshin. The interchromosomal index was highest (0.065) in accession Gembu and lowest (0.023) in accession Bokkos (1) (Table 3). The chromosomes were observed to be either metacentric or sub-metacentric (Fig. 1; Plate 1). 
Manchok

NRCRI (1)

NRCRI (2)

Hong (1)

Hong (2)

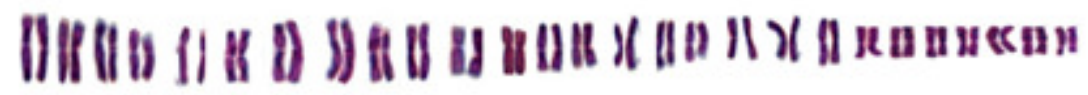
It in $n$ ss

Pankshin

Gembu

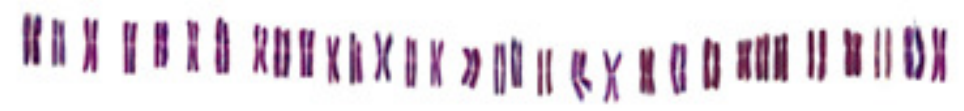

Lantang

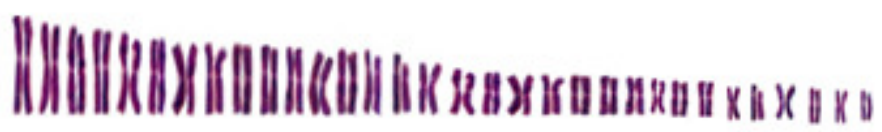

Bokkos (1)

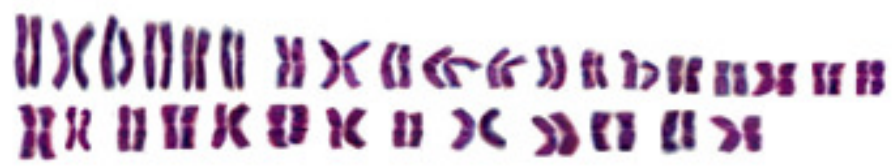

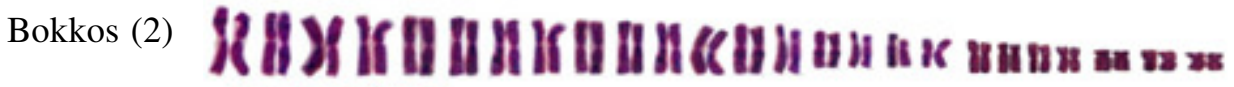

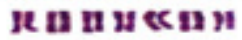

Figure 1. Ideograms of somatic cells of some Hausa potato accessions. 


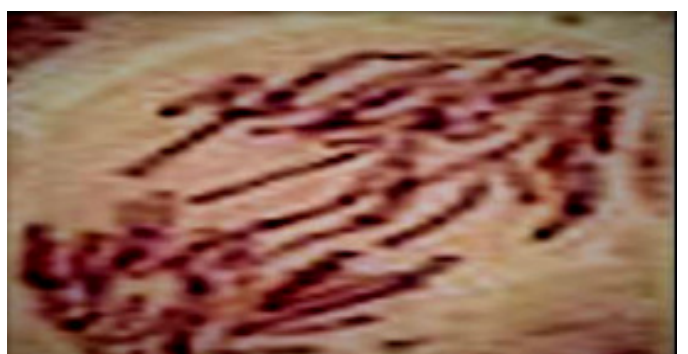

Manchok

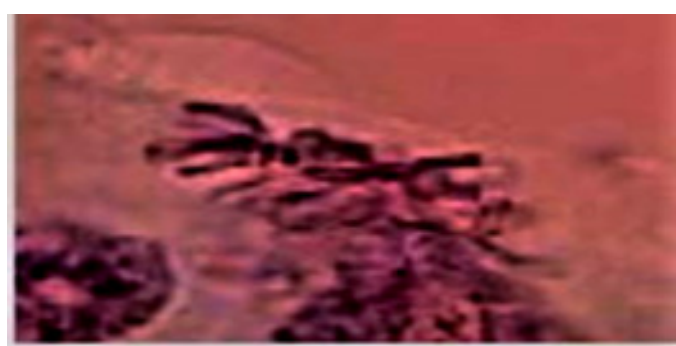

NRCRI (2)

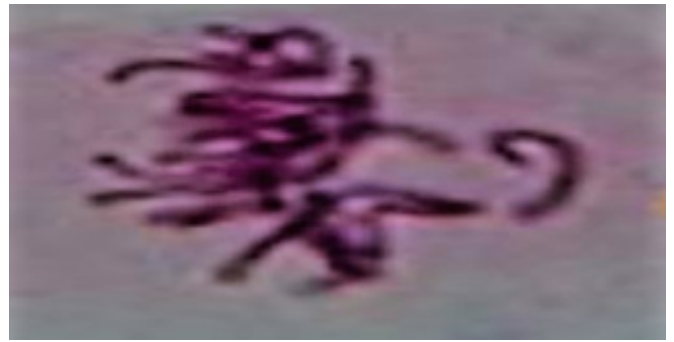

Hong (2)

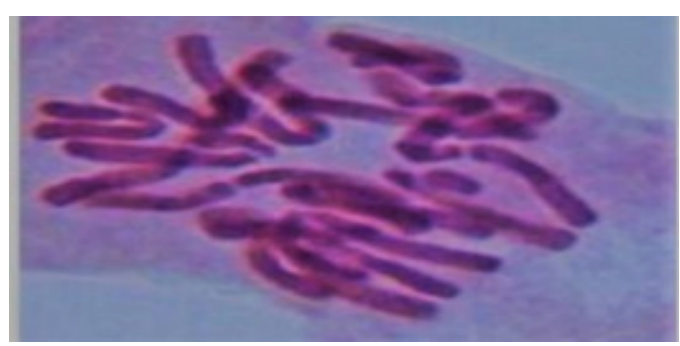

Gembu

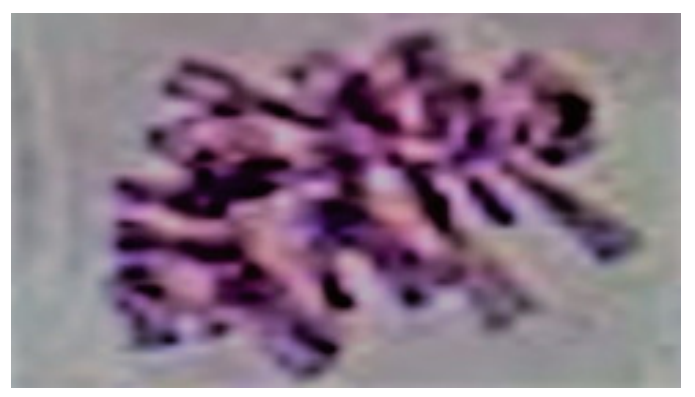

Bokkos (1)

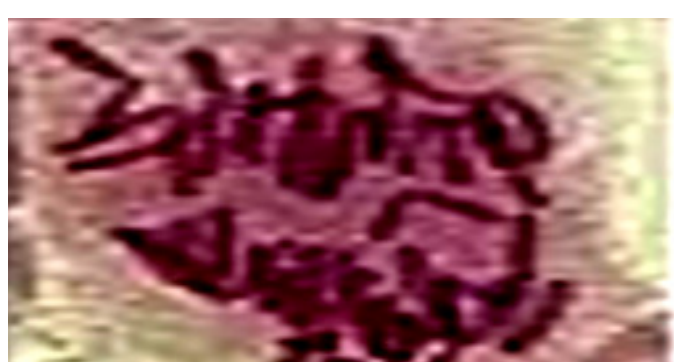

NRCRI (1)

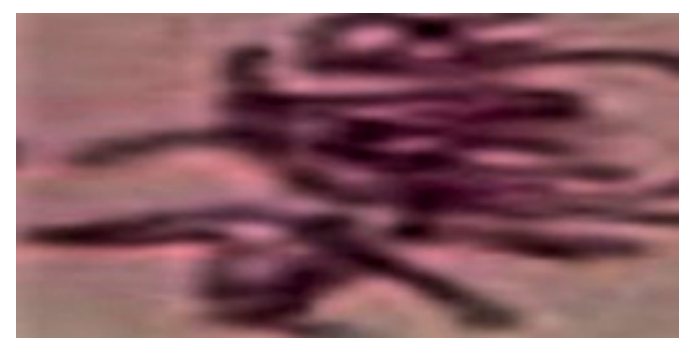

Hong (1)

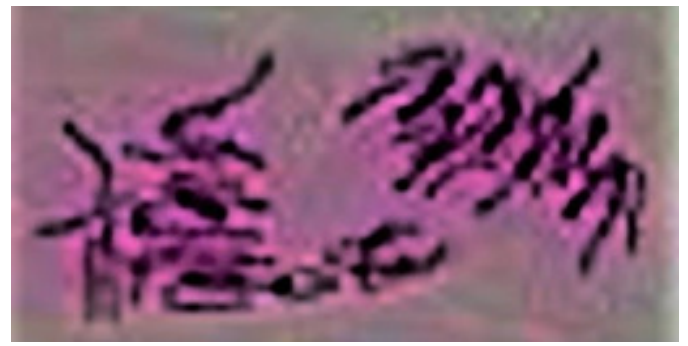

Pankshin

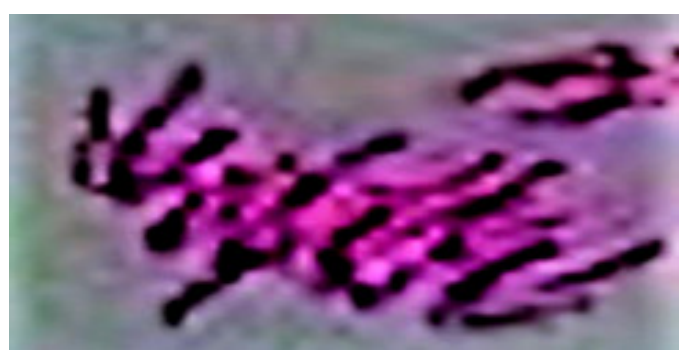

Lantang

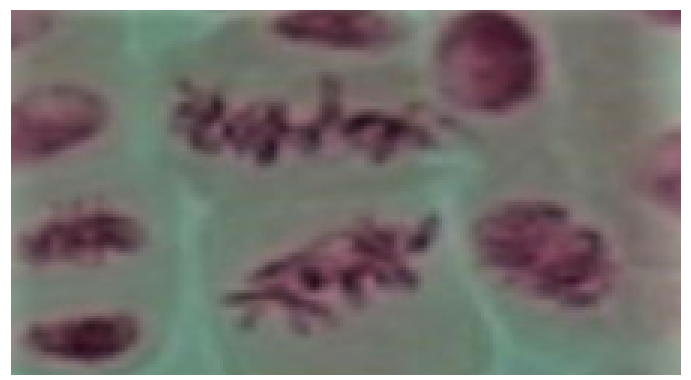

Bokkos (2)

Plate 1. Somatic cells of ten accessions of the Hausa potato. 
Similarity

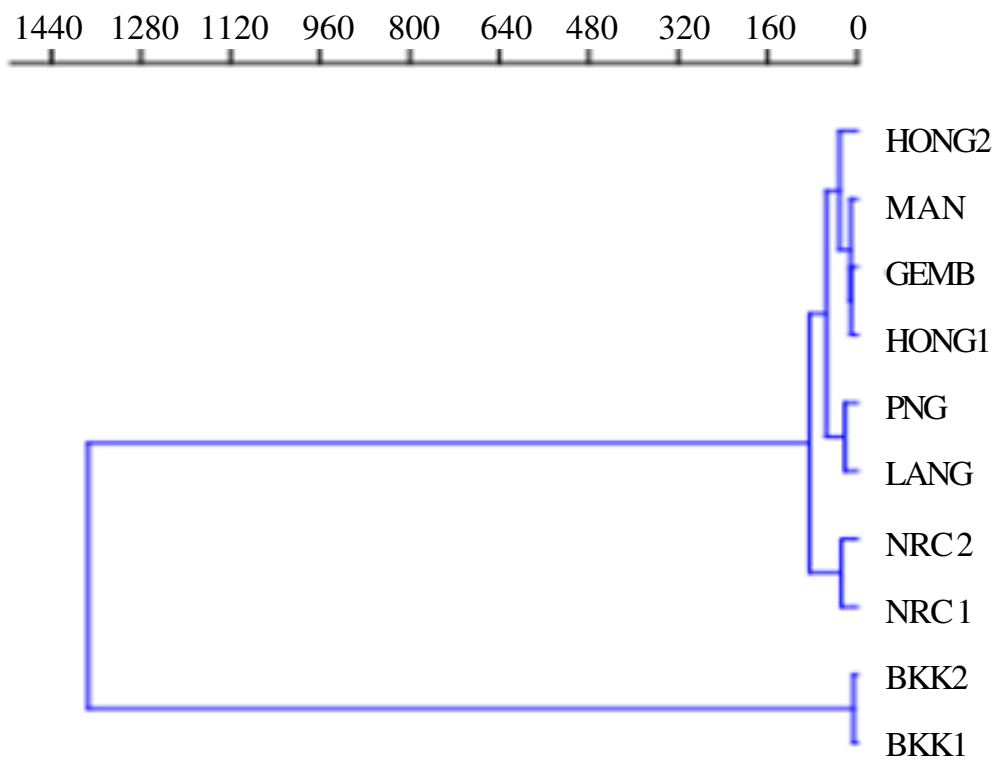

Figure 2. Dendrogram showing the phylogenetic relationship amongst ten accessions of the Hausa potato (constructed based on the Ward's method which is the matrix of karyotype distances) Cophenetic Correlation Coefficient $(\mathrm{CP})=0.462959403104521$. Key: HONG2 $=$ Hong (2), Man = Manchok, Gemb= Gembu, HONG1 = Hong (1), PNG = Pankshin, Lang = Langtang, NRC 2= NRCRI (2), NRC 1 = NRCRI (1), Bkk2 = Bokkos (2), Bkk1 = Bokkos (1).

In accession Manchok, twenty-eight chromosomes were metacentric; while four were sub-metacentric $(28 \mathrm{M}+4 \mathrm{Sm})$. In the accession NRCRI (1), twenty-five chromosomes were metacentric; while seven were sub-metacentric $(25 \mathrm{M}+7 \mathrm{Sm})$. In accession NRCRI (2), twenty-nine chromosomes were metacentric; while three were sub-metacentric $(29 M+3 S m)$. In accessions Hong (1), Hong (2), Pankshin and Bokkos (2) all the thirty-two chromosomes were metacentric (32M). In accessions Gembu and Langtang, thirty chromosomes were metacentric; while two were sub-metacentric $(30 \mathrm{M}+2 \mathrm{Sm})$. In accession Bokkos (1), twentysix chromosomes were metacentric while six were sub-metacentric $(26 \mathrm{M}+6 \mathrm{Sm})$ (Table 3$)$.

The phylogenetic relationships among the accessions were assessed using the cluster analysis. Grouping was based on the Euclidean distance co-efficient, using the Pearson's correlation. The accessions were grouped into four clusters. Cluster I consisted of four accessions (Hong (2), Manchok, Gembu and Hong (1)); cluster II consisted of two accessions (Pankshin and Langtang); cluster III consisted of two accessions (NRCRI (1) and NRCRI (2), while cluster IV consisted of two accessions (Bokkos (1) and Bokkos (2)) (Fig. 2).

The principal component analysis (PCA) based on karyotype parameters, showed that the first two components $\left(\mathrm{PC}_{1}\right.$ and $\left.\mathrm{PC}_{2}\right)$ accounted for $99.997 \%$ of the total variation, and these were projected in two dimensional graphic (Fig. 3).

\section{DISCUSSION}

The basic chromosome number of $2 \mathrm{n}=2 \mathrm{x}=$ 64 as was reported by Nkansah (2004) was confirmed in this study. The chromosomes were observed to be metacentric and submetacentric (Fig. 1; Plate 1). Variations in 


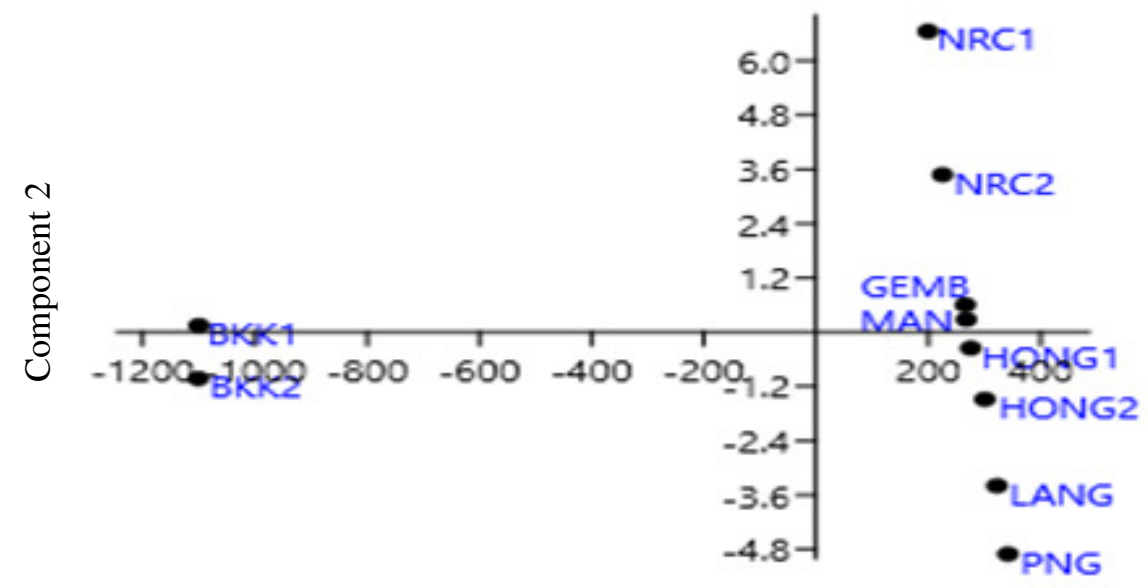

Component 1

Figure 3. Diagrammatic result of principal component analysis of ten accessions of the Hausa potato grown in Jos NRC1 = NRCRI (1), NRC2 = NRCRI (2), GEMB = Gembu, MAN = Manchok, HONG1 = Hong (1), HONG2 = Hong (2), LANG = Langtang, PNG = Pankshin, BKK1= Bokkos (1), BKK2 = Bokkos (2).

chromosome structure among the accessions were observed, as has also been reported for many plant groups (Maffei et al., 1999). Six karyotype classes were observed in the accessions studied. All the chromosomes in accessions Hong (1), Hong (2) and Pankshin were metacentric $(32 \mathrm{M})$.

Differences in the karyotype parameters among members of the same species, as observed in this study, have been reported to be due to the differences in relative length of haploid complement of chromosomes, arm ratio, centromeric index and chromosome type (Awe and Akpan, 2017). These differences may be due to chromosomal re-arrangements such as translocation, deletion or inversion (Mukherje and Ray, 2012). The karyotype can also be changed through inter-specific hybridisation or mutations in the natural populations (Awe and Akpan, 2017). Structural alteration of chromosomes is believed to result in the evolution of races, while the constancy of the karyotype within the population suggests adaptability to the micro-environmental condition to which they are subjected (Awe and Akpan, 2017). Differences in the karyotype formula (asymmetric karyotype) may be due to different geographic locations, suggesting that the genus Solenostemon has evolved into many different strains in different locations overtime (Awe and Akpan, 2017).

The coefficient of variation, total form (\%TF) and disparity index varied with the accessions (Table 3). The CV \% estimated for the homology of chromosome arms, spread over populations is used to determine the extent of variation among populations. Generally, the karyotypes of the populations in this study had either metacentric (centromere at median region) or submetacentric chromosome types. In other words, three populations were metacentric (32M), followed by $30 \mathrm{M}+2 \mathrm{Sm}$ ( 3 populations), $29 \mathrm{M}+3 \mathrm{Sm}$ (one population), $28 \mathrm{M}+4 \mathrm{Sm}$ (one population), $26 \mathrm{M}+6 \mathrm{Sm}$ (one population) and $25 \mathrm{M}+7 \mathrm{Sm}$ (one population).

The disparity index (DI) has been reported as a useful tool to differentiate quantitatively and closely related karyotypes belonging to the same clan of symmetry (Lavania and Srivastava, 1992). The high values of DI observed in this study suggests high levels of 
karyotype differentiation. The complement length), rather than small intrachromosomal index $\left(\mathrm{A}_{1}\right)$ and contributions of many characters. The interchromosomal index $\left(\mathrm{A}_{2}\right)$ showed slight variations among Hausa potato accessions studied. Variations in long and short arm lengths within and between populations form the basis of morphological variations among different accessions of the Hausa potato observed in this study. These variations could be used to determine the slight differences among populations (Romero-Zarco, 1986).

The results of cluster analysis showed that the accessions belonged to four clusters (Fig. 2). Some clusters were closely related, others were distantly related, suggesting genotypic or environmental differences.

In developing a crop improvement programme, a cross between distantly related accessions could result in a high degree of heterosis (hybrid vigour) in the first filial generation $\left(\mathrm{F}_{1}\right)$ and subsequent generations. Ghaderi et al. (1984) suggested that parents that are distantly related have the contrasting alleles at different loci, which recombine in $\mathrm{F}_{2}$ and $\mathrm{F}_{3}$ generations following crosses between the distantly related parents. Such crosses and recombinations provide opportunities for effective selection and crop improvement. Consequently, accessions in cluster I in this study could be crossed with those in cluster III; while those in cluster II could be crossed with those in cluster IV.

Principal component analysis was used to determine the variation in distance among the accessions studied. The principal components, $\mathrm{PCA}_{1}$ and $\mathrm{PCA}_{2}$, which were extracted from the original karyotype data, had a latent root greater than 1, and accounted for $99.997 \%$ of the total variation among the accessions studied. Characters with high absolute values within the first principal component are believed to influence clustering more than those with lower absolute values (Chahal and Gosal, 2002). In this study, the differentiation of the accessions into clusters might have resulted from a large contribution of a few characters (centromere position and arrangement of the accessions based on PCA conformed to the result of the cluster analysis. Differences in the karyotype formula and asymmetric indices found among the Hausa potato accessions, suggest that structural changes might have contributed to the diversification of the accessions studied.

Generally, crop improvement techniques such as selection and hybridisation depend, to a large extent, on the existence of variability. Genetic diversity or variations that relate to karyotype forms have been employed as a useful tool in assessing the crop improvement potentials of some crops (Bakshi et al., 2004; Dhamavanthi, 2005; Oyama et al., 2006).

\section{ACKNOWLEDGEMENT}

The authors are grateful to the University of Jos, Nigeria, for providing the enabling environment for this work; and Ahmadu Bello University, Zaria, for technical assistance.

\section{REFERENCES}

Abramoff, M.D., Magelhaes, P.J. and Ram, S.J. 2004. Image processing with image J. Biophotonics International 11:36-42.

Awe, E.T. and Akpan, U.U. 2017. Cytological study of Allium cepa and Allium sativum. Acta SATECH 9(1):113-120.

Bakshi, G., Neamati, M. and Zare-Maivan, H. 2004. Karyotype studies of the section Versicaria of the genus Trifolium in Iran. The Nucleus 47(1, 2):17-22.

Cai, J., Wang, H., Gu, Z.J., Mill, R.J. and Li, D.Z. 2004. Karyotypes of thirteen species of Pediculris (Orobanchaceae) from Hengduan Mountains region, NW Yunnan, China. Caryologia 57:337-345.

Chahal, G.S. and Gosal, S.S. 2002. Principles and Procedures of Plant Breeding: Biotechnology and Conventional Approaches. Narosa Publishing House, New Delhi, India. 112pp. 
Dhamavanthi, K.P.M. 2005. Karyomorphological analysis and phylogenetic relationships of Gossypium L. specie. Cytologia 70(4):421-427.

Egbaji, C.I. 2019. Cytomorphological study of the hausa potato [Solenostemon rotundifolius (Poir) J.K. Morton] in Jos, Plateau State. M.Sc. Dissertation. University of Jos, Jos, Nigeria. 114pp.

Eroglu, H.E., Simsek, N., Koc, M. and Hamzaoglu, E. 2013. Karyotype analysis of some Minuartia L. (Caryophyllaceae) taxa. Plant Systematics and Evolution 299:67-73.

Fujita, Y. 1970. Evolution of chromosome numbers in the Labiaceae, especially its relation to the classification and phylogeny of the genus Salvia based on constituents of essential oils. Acta Phytotaxon Geobot 24:113-121.

Ghaderi, A., Adams, M.W. and Nassib, A.M. 1984. Relationship between genetic distance and heterosis for yield and morphological traits in dry edible bean and faba bean. Crop Science 24:37-42.

Guerra, M. 2008. Chromosome number in plant cytotaxonomy: Concepts and implications. Cytogenetics and Genome Research 126:339-350.

Lavania, U.C. and Srivastava, S. 1992. A simple parameter of dispersion index that serves as an adjunct to karyotype asymmetry. Journal of Bioscience 17:179-182.

Levan, A., Fredga, K. and Sandberg, A. 1964. Nomenclature for centromeric position on chromosome. Hereditas 52:201-220.

Louzada, R.B., Palma-Silva, C., Correa, A.M., Kakchuk-Santos, E. and Wanderley, M.D.G.L. 2010. Chromosome number of Orthophylum species (Bromeliaceae). Kew Bulletin 65:53.

Maffei, E.M.D., Marin-Morales, M.A., Ruas, C.F. and Matzan-Naucher, N.L. 1999. Chromosomal polymorphism in 12 populations of Mikaniamicrantha (Compositae). Genetics and Molecular Biology 22:433-444.
Martin-Estra, J.C., Albo, C. and Benguria, A. 2011. Culture of human mesenchymal stem cells at low oxygen tension improves growth and genetic stability by activating glycolysis. Cell Death Differ 19:743-755.

Mukherjee, A. and Ray, S.C. 2012. Karyotype analysis of five species of Allium. Indian Journal of Fundamental and Applied Life Science (2):374-383.

Nanema, R.K., Traore, E. R., Bationo, P. and Zorgo, J. 2009. Morpho-agronomical characterization of Solenostemon rotundifolius (Poir) J.K. Morton (Lamiaceae) germplasm from Burkina Faso. International Journal of Biological and Chemical Sciences 3:1100-1113.

Nkansah, G.O. 2004. Solenostemon rotundifolius (Poir) J.K. Morton. In: Grubben, G.J.H. and Denton, O.A. (editors) PROTA 2: Vegetables/Legumes (CD Rom) PROTA, Wageningen, Netherlands.

Oyama, K., Henandez-Verdugo, S., Sanchez, C., Gonzalez-Rodriguez, A., Sanchez-Pena, P., Garzon-Tiznado, J.A. and Casas, A. 2006. Genetic structure of wild and domesticated populations of Capsicum annuum (Solanaceae) from northwestern Mexico analyzed by RAPDs. Genetic Resources and Crop Evolution 53:553-562. doi:10.1007/s10722-004-2363-1.

Oyuntsetseg, B., Friesen, N.W. and Darikhand, D. 2013. Allium carolnianum Dc., A New Species to the Outer Mongolia. Turczaninowia 16(2):88-90.

Ozcan, T., Gezer, E., Martin, E., Dirmenci, T. and Altinordu, F. 2014. Karyotype analyses on the Genus Lallemantia Fisch. \& C.A. Mey. (Lamiaceae) from Turkey. Cytologia 7 (4):553-559.

Paknia, R. and Karimzadeh, G. 2011. Karyotypic study and chromosome evolution in some Iranian local onion populations. Journal of Plant Physiology and Breeding 1(1):49-62.

Pavlova, D. and Tosheva, A. 2005. Notes on caryomorphology of Melilotus officinalis 
populations in Bulgaria. Caryologia 57:151- Peters, J.P. and Martineli, J.A. 1985.

158.

Peruzzi, L., Goralski, G., Joachimiak, A.J. and Bedini, G. 2012. Does actually mean chromosome number increase with latitude in vascular plants? An answer from the comparison of Italian, Slovak and Polish floras. Comparative Cytogenetics 6:371377.
Hierarchical cluster analysis as a tool to manage variation in germplasm collections. Theoretical and Applied Genetics 78:42-48.

Romero-Zarco, C.A. 1986. A new method for estimating Karyotype Asymmetry. Taxon 35:526-530.

Stebbins, G.L. 1971. Chromosomal evolution in higher plants. Edward Arnold, London. pp. 87-89. 